\title{
Status Offenders and the Psychosexual Gap in the Ugandan Law Regarding Defilement
}

\author{
Nathan Muwereza ${ }^{1}$
}

(C) Uganda Martyrs University

\begin{abstract}
This paper discuses defilement as a crime in relation to sexuality among adolescents in Uganda. Following a review of related literature, an extended field study of the prevalence of the practice and attitudes towards it was made. The findings were that, as a legal term, defilement has many theoretical and policing gaps and dilemmas. It was also found that the manner in which the practice is policed deters adolescents' sexual development. It is concluded that, in light of section 129 of the country's penal code act, consensual sex between adolescents may not be a crime. Therefore, it is argued that adolescents' smooth psychosexual development should not be sacrificed, notwithstanding the law regarding child sexual abusers, who must be punished stringently.
\end{abstract}

Keywords · Adolescents $\cdot$ Sexuality $\cdot$ Defilement law

Les Offenseurs de Statut and le Défaut Psychosexuel dans la Loi Ougandaise concernant la Défloration . Résumé - Cet article présente la défloration comme un crime en relation avec la sexualité parmi les adolescents en Ouganda. Suivant la revue de littérature liée à ce sujet, une étude prolongée sur terrain de la prévalence de cette pratique et attitudes a été faite. Les résultats ont montré que, comme un terme juridique, la défloration a plusieurs défauts et dilemmes de nature théorique ainsi que d'investigation. Il a été aussi découvert que la manière dans laquelle cette pratique est investiguée, empêche le développement sexuel chez les adolescents. Il a été conclu qu'en rapport avec la section 129 du code pénal du pays, le sexualité consensuelle entre adolescents ne peut pas être considérée comme crime. C'est pourquoi, il est demandé que le développement psychosexuel agréable chez les adolescents ne soit pas sacrifié, sans pour autant négliger la loi stipulant que les abuseurs du sexe de l'enfant doivent être punis sévèrement. Mots clé · Adolescents . Sexualité · Loi sur la défloration

\section{Introduction}

Several studies show that adolescents are sexually active worldwide (Moore et al, 2006; Remez, 2000; Bagley, 1997; Todd et al, 1999; Kane and Wellings, 1999; Stammers, 2001 and Coleman, 2002). While there are generally similar approaches to criminalization of sex between adults and children, there exist much nuanced methods of criminal sanctions to regulate sexual behaviour among adolescents. Yet, sexual offences, perhaps the most shameful offences among humans, are increasing worldwide. It was noted that sexual offences had increased in subsequent years in $\mathrm{UK}^{2}$,

\footnotetext{
${ }^{1}$ Albert Ludwig University, Germany, E-mail: nathanmuwereza@yahoo.co.uk 2See for example Povey et al (2000:1) on crime statistics in England and Wales.
} 
though typologies and prevalence vary. Astoundingly, studies that involve and relate to child sexuality and offending have tended to focus on child sexual abuse, whose profiling is also complex (Wazir and van Oudenhoven, 1998), at the expense of adolescents psychosexual development. The plight of status offenders is totally ignored.

Sexual offences have recently attracted lots of attention, and reactionary policies and legislations enacted in different countries. However, the aspect of sex between adolescents themselves is taken for granted and is often misinterpreted. Consent and appropriate ages appear to complicate legislation, criminal sanctioning and crime prevention efforts. Much of the legislations are based on adult yardsticks; treating adolescents as young versions of adults. Adverse effects of misguided programming in existing criminal justice institutions can actually contribute to crime (Silvester, 1987:121-122). Adolescent sexuality is a complicated aspect not only in criminology, but also in other spheres (Chalmers et al, 2006; Ingham and Aggleton, 2006). When adolescent sex offenders are viewed as children, they are over protected and absolved from moral responsibility. When viewed as adults, a tendency to deal more punitively with them prevails. ${ }^{3}$ Some behaviours and actions needn't be offences in real socially constructed worlds. Status offenders (teens, whose sexual behaviours are consensual but unlawful because of legal consent ages (Zimring, 2004)) are good examples. They are victims of unjust criminal sanctions that lack comprehensiveness, unappreciative of the interconnected psychosocial human behaviour and cultural disharmony. However, given the specific contexts within which sexuality and sexual relationships develop, sexual offences present complex cases for criminal justice systems. This study concerns defilement as a sexual offence among adolescents in Uganda and highlights gaps regarding status offenders thence.

\section{Methodology}

A review of literature on defilement regarding its meaning, prevalence and legal dilemmas was made early 2007. A prolonged field research through interviews and observations in parts of Uganda followed. Respondents included adolescents remanded for defilement, their victims, young adults and policing officers who were purposively selected. The responses were noted from 2007 through 2009. Question items were about the meaning of defilement, attitudes and factors affecting sexuality and legal dilemmas. Stand alone response texts are analyzed in this piece of work.

\section{Findings}

Here, the field findings are presented and contextualized within previously reviewed related literature, whose authors are acknowledged therein.

\section{Meaning of Defilement}

Defilement refers to a sexual crime in which the victim was up to 2007, a girl under 18 years of age. The word 'defile' compares with the word 'spoil'. Its meaning and intent implies that law guards against spoiling girls' sexuality. It was stated in the Uganda's Penal Code that any person who unlawfully has sexual intercourse with a girl under the age of eighteen years commits an offence and is liable to suffer death. ${ }^{5}$ Section 129 was later amended to include all persons below 18 years of age. It now punishes defilement of both sexes, irrespective of the age of the offender and the victim's consent, and corrects an anomaly which discriminated against boys. While the sexual vulnerability of children is acknowledgeable, adolescents in healthy, loving and consensual

3See also Reiss (1960) who in addition argued that the failure to accord adolescents a distinct status position that is closely integrated with the larger structure for governing their behavior has important implications for defining and sanctioning their sexual conduct in our societies.

4Wazir \& van Oudenhoven, (1998:3) indicated that lack of consensus in defining sexual offences is caused in part by multicultural societies; and noted that perceptions of what constitutes sexual abuse are culturally and socially determined, with the result that acts which are considered offensive in one cultural context may be quite normal in another.

5 See section 129 of the Penal Code Act - chapter XIV (in Chapter 120 of the laws of Uganda). 
relationships are being unjustly treated. Victims express their disappointment in this law as in the caption below.

"We've been friends since 12 now 15... we plan to marry after school. We're conversing... actually doing nothing like hmmm... sex (seems embarrassed)... they arrested him. That he defiled me. Crazy..."I don't understand this! Imprisoned for nothing! (Female 15)

Since sexuality entails broader meanings and not just vaginal penetration; encompassing entire personality (Costa and Wood, 2005), the above amendments were timely. Sexuality begins before birth through a lifetime, full development of which is essential for individual, interpersonal and societal well-being. The amendment provided for definitions of "sexual acts" to mean "penetration of the vagina, mouth or anus, however slight, of any person by a sexual organ—vagina or penis; the unlawful use of any object or organ by a person on another person's sexual organ". However, for consenting adolescents, this presents policing challenges, illustrated in a caption below.

"We had done nothing; we were only kissing and romancing. If they took me for a medical check in my... (Momentarily looks for words) ...private parts at that time, they would have proved that he is innocent. The problem is with my parents...they just conclude without proof" (female 17)

She implies that sex is only when vaginal penetration happens. Eroticism without penetration to her is not sex. This view is widely supported, as answers to the question of why people cheat implied hereunder.

"Women cheat because men always stimulate them but don't play sex. This is frustrating. I can't stand that myself!" (Female 30). "Some women don't want to play sex. They just want to be fondled, yet for us; we want to go in (laughs) before satisfaction. (Go in? where?). Don't pretend (talks amidst laughter)... can you stay outside and believe you had sex even if you finished?" (Male 33)

To them, sex happens when there's penetration. This is the same implicit meaning of the penal code provisions. If these be held, then, without proof of penetration, adolescents should be left to nurture their sexuality if they avoid penetration. More so, as it has turned out, the difficulty of ascertaining penetrations for consenting adolescents is hard for police. A police man lamented on policing defilement as hereunder:

“Today's girls want sex like food. In five cases I handled, girls are problems. They refuse to be checked or run away from home because parents pester them. And as you know, proof is through them, unless when they are pregnant," (Male 38).

The same law postulates that even suspicion that defilement is about to take place is punishable. Any person who attempts to perform a sexual act with another person below 18 years is liable to imprisonment. Adolescent attitudes to this are negative. See below;

"Defilement is unfair law! Mere suspicion of girlfriend means imprisonment! How can we marry? Get strangers? Have girl friend... plan marriage! May be they'll suspect sex...I don't really understand them. ... will they hide near... seeing who is doing what?” (Male 17)

An adolescent sex offender is an adolescent who performs a sexual act on any person under a legally specified age bracket ${ }^{6}$ or against the latter's will and consent. This definition exposes gaps of defilement, regarding status offenders. It assumes non-consensual sex, yet many adolescents have consented to having sex and many happily enjoy it. Arguing that adolescents cannot legally consent to sex is idealistic than realistic. See realities in captions below.

"We met at school in 2005. I was 16 and him 17. I visited him later in that year ...our first time was memorable... drew me to him forever. (Didn't he defile you?)... I liked it myself..., just

6 It is also unfortunate that legally specified age brackets and their definitions also present artificial barriers in many social contexts and complicate the sexuality of adolescents themselves and may be detrimental (see Levine, 2003). 
going there was enough... Otherwise, why go there? Had it almost every weekend... I was staying in a hostel while he rented nearby. (Pregnancy?)...we play it safe ... even now. Was young...but had feelings..." (female20)

The socio-economic and cultural contexts within which adolescents are raised impacts on their sexual will to engage in sexual intercourse and need to be put into consideration. See caption below.

"I don't believe defilement is crime. My first girlfriend was older...had money but liked me because I was bright... we had sex. She could arrange herself. I was young, just 15, but enjoyed it" (Male 26)

Criminality of 'status offenders' can't easily be located in existing theories of sexual offending in Uganda. These theories are extensively described and may be detailed in another article. Theories such as the integrated theory of the aetiology of sexual offending (Marshall and Barbaree, 1990), precondition theory of child sexual abuse (Finkelhor, 1984); the Child molesters' implicit theories (Ward and Keenan, 1999) all implicitly imply that only males sexually offend, yet females sexually abuse males. ${ }^{7}$ They only explain cases where offenders are adults such as child molesters; ${ }^{8}$ and/or where the sex is non-consensual, but not consensual sex between adolescents themselves.

It is contestable that criminal sanctions against healthy adolescent consensual sexual relationships create a healthy context for their sexual development and subsequent reduction of sexual offenses. Sex between adolescents is just part of normal human development and legal barriers will impinge the process and interrupt its smooth transitory nature (Levine 2003). This isn't suggesting that children should be left to play sex wherever and whenever, but that criminal sanctions are extremes, justification of which is practically and theoretically hard. Instead, proper contexts must be understood in developing or inhibiting desirable and undesirable behaviours. Contexts are important aspects in developing any social behaviour, whose understanding is important in tackling issues of adolescent sexuality.9 Policy contexts in which laws are developed need to be approached in light of other contexts such as communities, socio-economic correlates and personal psychosocial domains of adolescent sexual development. Otherwise, prevention of such offences shall continue being complicated among adolescents. It may not be surprising that the portrayal of the prevalence of defilement is obscured by considerations of adult-child sexual relationships at the expense of adolescent consensual sex.

\section{Prevalence of Defilement}

Few if any, empirical studies address the prevalence of defilement in Uganda. However, studies for different aims show that defilement is very prevalent. Adolescent sexual activity in Uganda is not only common, but implicitly goes on unabated (Atuyambe et al, 2005; Neema et al. 2006)). Elsewhere, studies show that more than $25 \%$ of adolescents below 18 years in Sub-Sahara have already given birth (Population Reference Bureau, 2006). More than 50\% of women 20-24 years, now married, did so before 17 years (UN, 1989).

Precise estimates of defilement are difficult to obtain especially in the context of status offenders because they are normally unreported as offences. Even disclosures by child sexual abuse victims are low (Robins, 2000). This explains why most empirical literature suggests defilement by implication. Categorically, defilement rates in Uganda are higher than documented or reported. Consensual adolescent sex is very evident and many don't consider it criminal. Is it probable that

7 "Male children are at clear risk from sexual victimization, misuse and abuse of developing sexuality. Gender differences often assumed to protect against this risk do not... We tend to be more protective of female than male children"' (Flowers et al, 1989:39): See also Robinson (2002) on sexually abusive teenage girls.

8 See for example Ward \& Keenan (1999), who argue that maladaptive implicit theories concerning the nature of victims and the world do generate cognitive distortions in child molesters to view children as sexual objects. 9 “...Whilst acknowledging that young people have varying desires, attitudes, knowledge, skills and abilities, a dynamic contextual analysis explicitly recognizes that there are, in all societies, forces that determine whether, how, when, with whom and where young people engage in sexual activity" (Chalmers et al, 2006:8). 
the conception and development of this legislation was reactionary and lacks social and community support? Many sexual encounters are consensual and their prosecution is complicated by victims' support for offenders. Unreported status offender cases appear not to constitute part of the prevalence of this offence. See the caption below.

"Many people cheat because they marry wrong choices. I and my girlfriend know what it means to be faithful to each other. (How old is girlfriend)... she is 16. (Had sex already?)... What? (Laughs) ... obvious!" (Male 22)

Defilement is reported if offenders don't pay or bribe (Magee, 2006). Where this is so, they're never mentioned, even in the media. According to official police statistics, between 2002 and 2003, defilement cases rose from 649 to $999 .{ }^{10}$ In the US, sexual offences against children are widely researched and presented, where some are even opting for oral sex as a form of abstinence and in fear of HIV/AIDS infections. ${ }^{11}$ Official statistics on sexual offences involving children also implicitly omit status offenders, strengthening the argument that adolescent consensual sex needn't be criminalized. The issue of sex between adolescents themselves remains complex. The difficulty of determining and proving its criminality cannot be underestimated. Whereas complexity and difficulty of policy and legislation is acknowledged, criminalization of consensual adolescent sex is no solution. Insofar as it can be ascertained, defilement and the plight of status offenders present legal dilemmas to criminal justice systems, their prevalence notwithstanding. Next is an exploration of some of these dilemmas.

\section{Legal Dilemmas}

Stringent legal measures to check some social behaviour may fail due to the complexity of such behaviour itself. In Uganda, the penal code, with its various amendments prescribes a penalty of death. However, these penalties are rare; not because people don't defile but because the cases are legally complicated. Consent for example is ideally a voluntary, sober, imaginative, enthusiastic, creative, wanted, informed, mutual, honest, and verbal agreement; a process which must be asked for every step of the way12. Although these are the ideals, in many societies and cultures, they are never all the case. In real life, these issues are often more complicated13. In Uganda, there is a popular saying: "a woman never says yes to sex even when she wants it. Her 'no' continues until orgasmic climax, responding with pleasure and thanks him for the work well done after intercourse. Women in Uganda have a popular perception that a quick yes indicates promiscuity.

Similarly, cultural upbringing nurtures women to be shy during fore play as revealed by sexuality groomers, the Ssengas (Tamale, 2005). It is hard to understand consent especially in socially constructed Ugandan societies. Men respecting 'no' are deemed weak. See caption below;

"The first time I visited him, he did nothing. I actually doubted him. I pretended a bit...he never probed further...some women gain easily when you somehow nag... persist. Anyhow, it later worked and we are finally happily here!" (Married female31).

This implies that they need some element of force in sexual relationships and men need to show capability. Rapists are not contextually supported here but intricacies in sexuality and offending in contexts in which successful criminalization and policing of sexual offences are highlighted.

Contrary, adolescents may fulfil the above ideals of consent but are considered offenders because of legal definitions of consent ages and this is of concern. According to Tan, (1999), the age of consent refers to the age at which a person's consent to have sex is recognized as valid in the eyes of the law. People who engage in sexual activity with adolescents below this age are therefore

10 See for example Baker, (2005: 22) on Multi-choice policing in Uganda, shows increases.

11 See also Griffiths (2006) and Stammers (2000:1520) in England, and Gates and Sonenstein (2000:295 in the US; and Remez (2000) on oral Sex among adolescents: Whether it is sex or it is abstinence!

12 Yisrael, D.S. (2005) advices that never assume, ask before you proceed. A good lover is a good listener. A bad listener is at best a bad lover and at worst a rapist.

13 See for instance Peterson and Muehlenhard, (2007:72), who, while observing that many people, including the public and researchers, treat sex as either wanted or unwanted, with wanted sex being consensual and unwanted sex being non-consensual also agree that real life is complicated 
guilty of defilement. This is true even if it was the adolescent who wanted sex and fully consented. The agreement of persons below consent age is simply invalid in the eyes of law. This is done in the name of protection of the vulnerable group, the children. However, the criterion for vulnerability among consenting adolescents is another aspect of controversy. Who among two adolescents who freely enjoy sex is vulnerable? Without ignoring females' sexual vulnerability, ruling out their psychosocial and emotional component of sexuality is not healthy either. Instinctively and naturally ${ }^{14}$, they will want sex. The criterion for defilement in Uganda has over stressed the vulnerability of adolescents at the expense of their freedom to relate and nurture their loving relationships. In this regard, ages of consent are portrayed as artificial limits on rights of maturing adolescents to individually choose and nurture love partnerships.

Whereas sexual violence, coercion and exploitation of vulnerable children should be criminalized and severely punished, consensual, well nurtured and loving relationships between maturing adolescents needn't be hampered in the name of protection. Society may not necessarily reap better results by protecting adolescents in this way. ${ }^{15}$ Arguing that criminalizing adolescent sex inhibits antisocial sexual behaviour is invalid because consensual sex isn't necessarily antisocial behaviour (Wilder and Watt, 2002). Maturing adolescents need to relate responsibly as their ages advance to allow them partner up smoothly. Unless issues of age (Zimring, 2004), consensual issues and precocity contexts (Parent et al, 2003) are streamlined, dilemmas abound.

Whereas the penal code amendments now cover persons under 18 years, defilement remains prevalent (UHRC, 1997), report laxity notwithstanding. Though accusations are launched in courts, convictions are not common due to the complexity of cases themselves. Because of this crime's multifaceted contextual stance, complicating legal practical approaches, those punished are few. Issues of evidence of penetration, witnessing by minors and evidence corroboration to prove them beyond reasonable doubt are indeed complex.

It has appeared in some cases that absence of medical evidence on penetration is not necessarily fatal to the prosecution in a defilement case. In the case of BASSITA HUSSEIN vs Uganda SCCA $35 / 1995$, it was held that though desirable, it's not a hard and first rule that the victim's evidence and the medical evidence must always be adduced in every case of defilement to prove sexual intercourse or penetration. Whatever evidence the prosecution may wish to adduce to prove its case, such evidence must be such that it's sufficient to prove the case beyond reasonable doubt. Further, it has appeared that absence of the victim's evidence is not necessarily fatal to the prosecution case in sexual offences. In the case of RUGARAWANA vs Uganda SCCA 39/1995, it was held that in a defilement case, an accused can be convicted of the crime on the basis of the testimony by the witnesses other than the victim for example medical evidence and eye witnesses. However, it is important to note also that in sexual offences, where the victim is a child of tender years, evidential rules make the prosecution case doubly difficult. There is need to corroborate the evidence of a child of tender years when the evidence is given on oath. In UGANDA vs BATURINE RICHARD HCC 589/1996, it was held that the evidence of a child of tender age requires corroboration and where a child of tender age is the complainant in a sexual offence, her evidence doubly requires corroboration. Where the accused denies the charge, the prosecution must discharge its legal duty of proving each and every essential ingredient of defilement against the accused. In KOLIL vs $\mathrm{R}$ [1959] EA 92, a child of tender years was held to be a child under the apparent age of 14. Corroboration in law means independent evidence which supports the testimony of the complainant. It is confirmation from some other source that the complainant is telling the truth in some part of her story and goes to show that the accused committed the offence. In KATUMBA JAMES vs Uganda SCCA 45/1999, corroboration was defined as additional independent evidence which connects the accused with the crime confirming not only the evidence that the crime has been committed but also that the accused has committed it. Under common law, the evidence of a

14 See for example Lastrucci (1942:215) once noted that the so-called nature-nurture problem undoubtedly is far from being settled, and perhaps will never be entirely a closed issue.

15 See also Levine (2003) who argues that trying to protect young people from sex can actually exacerbate or even create the much-feared sexual danger. 
complainant in a sexual offence must be corroborated with either direct or indirect circumstantial evidence. Considering all these, prosecuting status offenders becomes additionally hard. Lovers will do anything to make prosecution proceedings fail. Will girls be forced to take medical examinations? How about their rights? All these issues complicate matters for judges in courts. Moreover, every judge must warn himself and the assessors against the danger of convicting an accused person on the uncorroborated evidence in a sexual offence. In the case of KIWANUKA vs UGANDA, criminal appeal 41/1995, the Supreme Court held that it is settled in law that in sexual offences, though corroboration of the prosecution evidence is not essential in law, in practice it is always looked for and it is the established practice to warn the assessors against the danger of acting upon uncorroborated evidence.

The justification for the requirement of corroboration in cases involving sexual offences was expressed by Lord Justice Salmon in R vs HENRY AND MANNING, when he guided that the judge has to use clear and simple language that will without any doubt convey to the jury that in cases of sexual offences, it is really dangerous to convict on the evidence of the woman or girl alone. This is dangerous because human experience has shown that in these cases, girls or women do sometimes tell an entirely false story. It's very easy to fabricate but extremely difficult to refute.16 Note that the rationale for corroboration is that given the nature of the offence, the allegations may be difficult to verify. Yet this is in cases where there was no consent. In cases where adolescents consent to sex, it is entirely difficult for the legal process. The girl just complicates everything by denying to have had sex with the boy. The United Kingdom's equivalent of defilement law in which the victim and offender are adolescents is in section 13 of Part I of the Sexual Offences act 2003. While there are explicit descriptions of what sexual acts should happen for the offender to be convicted, defining a sexual act is quite complex. The Act does not include a list of actions which are considered sexual. Although ways of determining them are set out, they all are at the discretion of the jury. ${ }^{17}$ In regard to consenting adolescents, the jury may not ascertain such acts with ease. Even reaching court alone may be problematic because there is no offender in reality, neither is there a victim/complainant.

From adolescent consensual sex point of view, it is plausible to observe that the legal dilemmas are in part, a result of the juxtaposition of the law with a behaviour that is normal, healthy and liked by involved parties. Adolescent females describe sex as "being beautiful", something "to be fulfilled, like hunger or thirst", as "an act of love", "a way for you and your lover to get closer", and "makes the relationship better ( $\mathrm{Ng}$ and Kamal, 2006). Consensual healthy sex is therefore understood as a behavioural act that has no harm to third parties or society as a whole. However, fear of the actions of sexual abusers and paedophiles on young people impels enacting laws with hope. Nevertheless, the proper understanding of contexts within which adolescent sexual behaviour develops, and factors contributing to prevalence of adolescent sexual involvement may offer insights into better strategies than criminalization, whose practical and theoretical justification is seemingly hard.

\section{Why Adolescents Engage in Sex}

Despite very stringent penalties in Uganda, defilement is on the increase. Almost every end of year, the Uganda Human Rights Commission releases human rights reports and these never miss issues on defilement. Moreover, these reports rightly don't consider consensual adolescent sex as an abuse. The question of why adolescents engage in sex can't be provided with a universal answer. Social phenomena's aetiology is complex but those relating to defilement, especially regarding adolescents, is more complex and interwoven. Adolescents' objectives for engaging in sex and the circumstances under which they do so vary and depend on several factors (Stammers, 1998).

16 See for example, Henry, R. vs. Manning [1969] 53 Cr. App. R 150 at 153

17 There are basically two categories of acts which are "sexual" for the purposes of this law. The magistrate or jury have to decide whether a reasonable person would consider either that the particular act is, by its nature, sexual; or whether it could be sexual, AND either because of the particular circumstances and / or the offender's intention, it is sexual (Rights of Women, 2006) 


\section{Cultural Practices in Form of Initiation Ceremonies and Rituals}

Tribes in Uganda hold different cultural beliefs and rituals that have implications for adolescent sexuality. What adolescents go through in each tribe may provide some explanations for early or late sexual involvement. Some of them are so complex and socially ingrained that the law cannot easily comprehensively cover them. Yet in the era of technology, formal education and globalization, people of different tribes continuously interact and so are their children. Cultural practices are thus permeating and being copied in several ways. Only two rituals for two tribes area used here to illustrate the point since there are over 50 tribes in Uganda.

\section{Initiation into Womanhood among the Baganda}

The Baganda initiate their girls into womanhood through rituals that involve pulling the labia and rubbing various herbs onto them (Neema, 1994). A precondition for marriage, carried out before onset of menstruation, if a bride has not pulled, the aunts get ashamed and despised. ${ }^{18}$ Through acculturation, ${ }^{19}$ girls of other tribes have been influenced. However, the sensations caused by this process stimulate sexual feelings and develop sexual curiosity. These, coupled with adolescence sexual energies may insinuate adolescents into early sexual involvement. Elongated labia enhance eroticism. When touched during foreplay, they are sources of immense pleasure to the couple (Tamale, 2005). Most men interviewed enjoyed sex with women having stretched labia and women enjoyed the sensation. Contextually, touching and rubbing of herbs on the clitoris of young girls may sexually arouse them. It makes them imagine pleasure and eroticism derived if with lovers. It follows that any intimacy opportunity with boys result into sex; likeable experiences where consent is implied. The criminalization of such pleasure especially if attained with fellow adolescents in responsible relationships may be unjustified, if not very difficult to police.

\section{Circumcision Rituals, Ceremonies and Manhood}

Circumcision of adolescent boys and ceremonies among Bagisu to initiate them into manhood provide avenues for early sexual involvement (Heald, 1982). During the ceremonies, the opportunities to leave home arise. It is believed that during this time, many are incited into sex. ${ }^{20}$ The dances are such that girls are touched in sexually arousing ways. Another important feature is that circumcision confers immediate adult status on initiated youths. They become adults, independent members of society and men (La Fontaine, 1967), expected to have their own huts and freely have sex. In essence, even 14 year-olds who are circumcised become adults. In addition, the ritual requires that freshly healed penises be sexually tested, meaning that adolescents have sex before marriage or while young. Criminalizing such sex is complicated and it is not surprising that many youths play sex and this law does little about it. In modern times, there exist little hindrances to aspects of sexuality such as myths that inhibited adult-child interaction in relation to sex education (Walker and Milton, 2006). The current open social lifestyles and technology play a role in educating youths. Accompanied by side effects in form of indiscriminate media information, pornography and internet sex, technology increases than reduces adolescent sexual activity.

18 Arrangements will be hurriedly made for effecting the elongation if it is discovered that a prospective bride has not been prepared in this way (Adeokun et al, 1995:19). Note also that a [Muganda] woman who did not elongate the labia minora is traditionally despised and regarded as having a "pit" (kiwowongole, kifufunkuli, funkuli muwompogoma). If a bride was found not to have elongated her labia minora, she would be returned to her parents with disgrace (Sengendo and Sekatawa, 1999).

19 Acculturation is the process of changing one's culturally accepted act/behavior due to continuous contact with another person(s) from whom the act is copied, although Castles, (2003:23) calls it assimilation theory

20 See for example Kataami and Akola, (2002), noting that during circumcision period (even years) the major activity is dancing to traditional music and drinking alcohol, which incites the people to sex. 


\section{Media, Pornography and the Internet}

The media has a powerful influence on behaviour and has had its share on sexuality. The Red pepper tabloid in Uganda and its depiction of sex raises curiosity among adolescents; imagining what it can be if tried. People are pictured having sexual intercourse or, at least, depicted to be doing so. Such pictures have different messages to different people, but most words that follow them insinuate sex and are pornographic. ${ }^{21}$ They can arouse sexual feelings in any sexually active person. Many radio and TV programs are sexually arousing, yet audiences are not always discriminated. Adolescents explore varied information sources to address curiosity about sexuality, about pornography and about sexual lifestyles (Longo, 2004:58). Such may arouse them to high heights of eroticism. All push adolescent into trying out! See caption below:

"Defilement is a useless law; I can play on line... or even just talking to her... (Do it on line?)...

Yah, it's called internet sex. This is modernity you know..., let them waste time... anyway, protect the ignorant" (Male 23)

Worsened by Uganda's lack of legal sanctions on pornography, criminalizing adolescent consensual sex is difficult and seems not a solution. It is really hard to police a liberally volatile adolescent in the open modern environment and in the era of technology. Even in developed countries, comprehensive strategies to discriminate what can be accessed by adolescents are complicated. Pornography includes sexually explicit material such as pornographic literature, movies, videos, live shows, photographs, and computer related pornography (Flowers, 2001). But keeping adolescents out of all these is uneasy. Curious literate adolescents can access illegal adult webs in the absence of parents. Imagine the amazement and further curiosity such webs can breed in their minds. Yet, in the current era, computer knowledge is almost a must for finding the best fit in the expanding but yet narrowing globe. Policing adolescents on what to search on internet is had.

Pornography is illegal when it is perceived to be obscene (Illman and Newcombe, 2006). This is different to being 'sexually explicit'. Whether a pornographic article is obscene is something that is traced and decided by a jury. However, traceability and anonymity are extremely complex, since tools used in identifying perpetrators can be used by them to identify potential victims. Also, issues of making, possession and storage in the computer era can be complicated to prove. Children themselves may be perpetrators, their curiosity notwithstanding. Moreover, such exposure pressurizes them to have sex even among themselves (Stammers, 1998), criminalization of which remains unjustified if not difficult.

\section{Attitudes and Emotions}

What we like or dislike makes us do or not do it. The impetus for engaging in sexual activity may be derived from such likes and dislikes. However, there is much more than just liking or disliking. Considerations of emotional and pleasurable components of sexual acts are important. Adolescent engagement in sex is due to sexual pleasure and expressing love among others $(\mathrm{Ng}$ and Kamal, 2006). Although the reasons and attitudes towards sex changed with time and experience, most don't regret having sex and losing virginity. See transcription below:

“... first time wasn't enjoyable. It hurt even when I wanted... later, it became normal, pleasurable and I wanted more" (Female 24)

Feelings are dynamic and can change before, during and after any sexual encounter and differences exist regarding males and females. ${ }^{22}$ But they seem to naturally occur in humans and compel them to engage in sex even when attitudes are to the contrary. There are substantial attitudinal effects on

21 Pornography is "any sexually explicit and/or titillating, arousing written, photographic, pictorial (including moving pictures) or live depiction of women or children for commercial exploitation... or acts to the population-at-large that have an effects on certain elements of society (Flowers, 1987:48)

22 See also Haseltonu and Buss (2001) who after considering reports of presex and postsex feelings, found that men with high numbers of sex partners, but not men with low numbers of partners, experienced a decrease in their partner's physical and sexual attractiveness following first-time sexual intercourse. In contrast, women, more than men, experienced increased feelings of love and commitment following first-time sex. 
first sex for males and females (Meier, 2003). Guilty feelings may follow consensual sex but pleasurable feelings experienced during intercourse may not be regrettable. Majority of adolescents reported being happy their most recent occasion of sex (Donald et al, 2003). While sex may involve emotional components, the reasons for indulging in it may be influenced by other factors.

\section{Socioeconomic and Health Factors}

The power of wealth, general attainment and statuses in society cannot be underestimated in pushing young people into sexual relationships, among themselves or with adults. The sexual relationships between adults and adolescents have been termed as sugar daddy or sugar mummy relationships. Adolescents, especially girls trade sexual services for goods and money (Kuate-Defo, 2004:17). In such circumstances, prosecuting such offences is difficult because victims view offenders as providers and defend them in courts.

On the other hand, relationships between adolescents themselves with similar connotations are common. When financial potential is foreseen in any family lineage, the interested party may do anything to get hooked to it; either by encouraging sex intending pregnancy to affirm their commitment or elicit sexual encounters so as to legally extort financial gains. "For a multitude of reasons, females may accuse men of sexual assaults to extort money ... when pregnancy results and ..." Menon (1983:834). Poverty in Uganda makes adolescents to get sexually involved to avert it and improve their economic statuses. This is more so when less education (Singh et al, 2001). It is in such complexities that the work of the legal and criminal justice system in any country turns out to be extremely difficult.

On health, there is a popular view in the Ugandan general public that defilement is increasing because of beliefs that young girls are HIV/AIDS free; and that many go for them with the intention of finding virgins. However, most cases that are reported involve people who don't make the intellectual connection between avoiding infection and having sex with minors (Adeokun et al, 1995:20). What is most disturbing is that some of these offenders are parents; with children in the same bracket as their victims. Even if polygamy is legal in Uganda, a man of 60 years, with children of over 18 years; to go for 14 year old girls is paradoxical. These are the people, if proved to have no mental problems, genuinely disserve death. Arguably, poor parenting and problematic family structures are a cause for adolescent engagement in sex and defilement.

\section{Familial Factors and Socialization}

Parents and family members are immediate environments for all children. They form the Microsystems that impact on children's development more intimately (Bronfennbrenner, 1979). Parents therefore have profound effects on sexual behaviours of their children. Wilder and Watt, (2002) established that just as unsafe parental behaviour increases the chance that adolescents will drink, smoke, or use drugs, parents who engage in risky behaviours may encourage early sexual activity by providing a model of low self-efficacy. It's been observed that exposure of children to risky behaviours has implications to their subsequent behavioural development. ${ }^{23}$ Conversely, consensual loving sexual involvements among parents are part of likely modelled behaviours yet they are out of these "risk" connotations. This is arguably because sexual activity may not necessarily be risk behaviour. It does not necessarily lead to sexually irresponsible behaviour. Therefore, sexual activity is partly a result of socialization and consensual sex is part of this socialization. Criminalization of such seemingly socialized and normal behaviour may not only be polemical but also hard to practically defend.

23 Marshall and Barbaree (1990:263) noted that exposures to the experiences typical of a sex offender... make them relatively unable to develop intimacy and to feel empathy... leaves them inept, lacking in confidence, self-centered, hostile, aggressive, and negatively disposed to women. This makes adjustment from adolescence to adulthood hard. 


\section{Implications, Recommendations and Conclusion}

At this point, it is imperative to appreciate the fact that criminal justice and policing of crimes of a sexual nature in society have implications for sexual health and general societal wellbeing. If not harmoniously approached the sexual health and development of children and young adults is in jeopardy. It is a humble submission that if some level of such harmony is to be attained, there is a need to consider seriously kinds of behaviours being criminalized along the following:

\section{Research and Theorizing}

No explicit theory covers issues of status offenders in their entirety. The law appears to lack theoretical background, implying that criminology has not offered a theory upon which such offences can be attested. This complicates its applicability in the real social world. Research and theory need to provide explanations and justifications for criminalizing adolescent consensual sex. It is not enough to say that young females cannot consent to sexual encounters as provided by the law. The truth is that they consent, like and enjoy sexual experiences. Putting laws in place that don't have a basis raises issues of legitimacy and defiance (Tyler, 1990). Even mainstream theories of criminology fail to explain why defilement is so prevalent despite its stringent punishments. Offenders aren't willing to change choices (Von Hirsch et al, 1999). Consensual adolescent sex prevails as if it isn't a crime, punishable by death. Essentially, all those who are not virgins and are below 18 years are victims or criminals in Uganda. This is not a small number though. Practically, many would be hanged or in prisons for life.

Whereas adolescents don't feel offended, the law criminalizes them and finds itself in practical and technical difficulties of proving offender's guilt. The argument that the state protects vulnerable groups does not significantly justify criminalizing adolescent consensual sex. The vulnerable become victimized if they have to help in prosecution (Levine, 2003; Magee, 2006). How the criminalization of consensual sex among and between adolescents is justifiable remains an aspect of further research. Consequently, without proper empirical studies and provision of theoretical frameworks within which criminalization of consensual sex can be defended, the sexual autonomy, part of the human freedoms of adolescents is unjustly curtailed.

\section{Sexual Autonomy}

Sexual autonomy is viewed to include the right to engage in wanted sex and to be free and protected from unwanted sex. It is only when both of these aspects are recognized that human sexual dignity can be considered fully respected (Graupner and Bullough, 2005). This implies that rights and freedoms of adolescents are being compromised by defilement laws. There needs to be clear distinctions between children and adolescents in sexuality and crime. Treating adolescents as children is unfair not only to them but also to society at large because they need nurturance to find and form marriage relationships with responsibility and autonomy. While child sexual abuse shouldn't be condoned, sex between maturing adolescents is healthy and needn't be made scary, lest future parents get spoilt. Instead, help them build personal values for expressing emotions in clear and respectful ways, shape peer norms that value expressing emotions in respectful ways. Increase their knowledge and help them develop skills that enable them care for their bodies. In this way, future parents are developed than imprisoned or hanged. Adolescents are naturally curious and seek out sexual stimuli. Parents, educators, professionals, and caregivers should not panic when they discover children's natural curiosity and exploration (Long, 2004). Instead, use such times as 'teaching moments,' and guide adolescents to age appropriate materials. Many Uganda parents are ignorant and children appear to know more. Children openly asking questions relating to sexuality have their parents appear embarrassed. Parents need to adjust to these new trends through holistic adult and health programs. This will help them know how to responsibly bring up children to fit modern trends than criminalizing their rather naturally and socially relevant behaviours. In the event of criminalizing, there is need to consider all contexts lest laws become victims of challenge and ridicule. 


\section{Contextual Harmony}

Criminal justice needs to seek to attain harmony of contexts within which sexual behaviours of adolescents are exhibited. The questions of why, how, where and with whom adolescents engage in sex (Chalmers, et al, 2006), need to be critically analyzed and addressed when legislating. The social, cultural, economic and political dynamisms in societies need to work harmoniously to render the legal frameworks plausibly relevant. Appreciation is made of the fact that integrating all these contexts into a unified and consensual point is hard, but making a fool of the law like it is in defilement is not worthy, neither can it be the best option. Sexual and reproductive health poses considerable additional challenges that need consideration, including rafts of religious, cultural, social and community attitudes that affect responses of those in positions of influence (Ingham and Mayhew, 2006). The same challenges are posed to adolescents themselves and the criminal justice system as a whole. Adolescents' challenges are worsened by psycho-biological components of their sexuality. Hard as they may be, it is until such contexts are somewhat harmonized that legal procedures can attain their intended goals. Otherwise, the legal war on defilement especially in regard to status offenders in Uganda seems to have been lost.

\section{Sexual Health and Policing}

The tendency to pry or to be seen to pry into adolescents' sexuality is of paramount concern and implication for their sexual development and health. Young people end up having sex with guilt, and more preoccupied by secrecy at the expense of sexual and reproductive health. Sex is stealthily and hurriedly had, with less concern about pregnancies or HIV/AIDS. Adolescents don't take precautions (to use condoms or pills) after getting any slightest opportunity to have sex. In this respect, adolescents need relevant information and nurturance to make informed decisions about sex. The educational and health systems need to work harmoniously with the family structures to address this rather complex aspect of human life. Threats and criminal sanctions may help but not as effectively as proper information provision.

Complicated by perceptions of corruption or bribes, ${ }^{24}$ the work of the police has indeed been complex, yet few seem to appreciate such dilemmas. It is therefore important that issues of how to effectively police sex offences among minors are given priority in research and policy frameworks, the intricacy of their criminalization notwithstanding.

\section{Conclusion}

The legal approach to defilement in the Ugandan context and regarding adolescent consensual sex is flawed. The little strengths are overshadowed by weaknesses stemming from treatment of adolescents as young versions of adults, indiscriminate age bracketing, consent and lack of contextual harmony. Criminalization of adolescent consensual sex cannot be well located in the existing theories of sexual offending. As a consequence, its practical and effective implementation is complicated and difficult in legal terms. The prevalence of defilement is confusing and hard to quantify in Uganda. Portraying adolescent consensual sex as a crime remains largely in legal documents. Otherwise, much literature portrays it as a healthy problem than a crime.

On the contrary, the strengths of defilement relate to its ability to protect children from sexual abusers. Child sexual abusers and paedophiles cannot and should not be protected. Neither should adolescents who sexually abuse, assault or rape others be criminally absolved. Juvenile courts should function, their structural defects notwithstanding. Although defilement as a legal term has flaws especially in regard to status offenders, avenues for its necessity and applicability exist and are paramount. However, this necessity has practical complications due to contextual interconnectedness within which sex is perceived and enjoyed in different societies and countries, all of which have various implications.

24 The CIET found out that in Uganda, the police service was identified as the public sector most in need of reform. Nearly $60 \%$ of Ugandan respondents had been asked for a bribe by the police. 


\section{References}

Adeokun, L. A., Twa-Twa, J., Ssekiboobo, A. and Nalwadda, R.1995. Social context of HIV infection in Uganda. Health Transition Review supplement to volume 5, 1-26.

Atuyambe, L., Mirembe, F., Johansson, A., Kirumira, E. K and Faxelid, E. 2005.Experiences of pregnant adolescents - voices from Wakiso district, Uganda. African Health Sciences 5 (4), 304309.

Bagley, C. 1997. Policies for gay and lesbian youths. In: Bagley, C. (Ed) Children, Sex and Social Policy: humanistic solutions for problems of child sexual abuse. England: Aldershot, 176-185.

Baker, B. 2005. Multi-choice policing in Uganda. Policing \& Society 15(1), 19-/41.

Bronfenbrenner, U. 1979. The Ecology of Human Development: Experiments by Nature and Design. Cambridge, MA: Harvard University Press.

Castles, S. 2003. Towards a sociology of forced migration. Sociology37, 13-34.

Cater, S. and Coleman, L. 2006. Planned teenage pregnancy. Perspectives of young parents from disadvantaged backgrounds. London: The Policy Press.

Chalmers, H., Aggleton, P., Ingham, R. and Stone, N.2006. Dynamic contextual analysis of young people's sexual health. University of Southampton: Safe Passages to Adulthood Program. Centre for Sexual Health Research.

CIET.1999. Accountability in Police Departments CIET social audits Bolivia, Nicaragua, South Africa, Tanzania, and Uganda', (on-line) available from: www.ciet.org/en/documents/themes_docs/200622016515.pdf[Accessed 20 October 2010].

Coleman, L. 2002. New opportunities for reducing the risk from teenage pregnancy - what is the evidence base for tackling risk behaviours in combination? Health, Risk and Society 4(1), 7793.

Costa, S. and Wood, S. 2005 Sexuality and Social Change: Making the Connection. New York: Ford Foundation.

Donald, M., Lucke, J., Dunne, M. and Raphael, B. 1995. Gender differences associated with young people's emotional reactions to sexual intercourse. Journal of Youth and Adolescence 24(4), 453-464.

Finkelhor, D. 1984. Child Sexual Abuse. New Theory and Research. New York: Free Press.

Flowers, R. B. 2001. Sex Crimes, Predators, Perpetrators, Prostitutes, and Victims: An Examination of Sexual Criminality and Victimization, Illinois: Charles C Thomas. Publisher, LTD.

Flowers, R.B.1987. Women and Criminality: The Woman as Victim, Offender and Practitioner, Westport: Greenwood Press.

Gates, G. J and Sonenstein, F. L. 2000. Heterosexual genital sexual activity among adolescent males. Family Planning Perspectives 32(6), 295-304.

Graupner, H. J. D and Bullough, V. L. (Eds.) 2005. Adolescence, Sexuality, and Criminal Law; Multidisciplinary Perspectives, USA: Haworth Press.

Griffiths, D.2006. Adolescent Angst. Priory Group survey, London: Priory.

Haseltonu, M. G. and Buss, D. M. 2001. The affective shift hypothesis. The functions of emotional changes following sexual intercourse. Personal Relationships 8(4), 357-369.

Heald, S. 1982. The making of men: the relevance of vernacular psychology to the interpretation of a Gisu ritual', Journal of the International African Institute, 52(1), 15-36.

Illman, J. and Newcombe, R. 2006. Sex and the law: how does it affect you? (Online).Availablefrom:www.channel4.com/health/microsites/0-9/4health/sex/sar_law.html [Accessed12 April 2007].

Ingham R. and Mayhew S. 2006. Research and policy in young people's sexual health. In: Ingham, R., Aggleton, P. (Eds.) Promoting Young People's Sexual Health. International Perspectives. Oxon: Routledge, 209-225.

Ingham, R. and Aggleton, P. (Eds.) 2006. Promoting Young People's Sexual Health. International Perspectives, Oxon: Routledge.

Kane, R. and Wellings, K. 1999. Reducing the rate of teenage conceptions. Data from Europe. London: Health Education Authority. 
Kataami, K. A. and Akola, A. C. 2002. HIV transmission and risk factors associated with circumcision among Bagishu community, Uganda', International Conference on AIDS, July 712; 14: abstract no. ThOrE1460, Kampala: Joint Clinical Research Centre.

Kuate-Defo, B. 2004. Young people's relationships with sugar daddies and sugar mummies: what do we know and what do we need to know?' African Journal of Reproductive Health, 8(2), 1337

La Fontaine, J. S. 1957. The social organisation of the Gisu of Uganda with Special Reference to their initiation ceremonies. Ph.D. thesis, Cambridge University

Lastrucci, C. L. 1942. A reconsideration of the so-called sex instinct', Social Forces 21(2), 215217.

Levine, J. 2003. Harmful to Minors: The Perils of Protecting Children from Sex, New York: Thunder's Mouth Press

Longo, R. E. 2004. Young people with sexual behaviour problems and the internet. In: Calder, M. C. (Ed.) Child Sexual Abuse and the Internet: Tackling the new frontier, Dorset, UK: Russell House Publishing, 57-67.

Magee, R. K. 2006. Financial incentives to financially settle defilement cases undermine Uganda's efforts', American Bar Association- Washington DC: Africa Law Initiative.

Marshall, W. L. \& Barbaree, H. E. 1990. An integrated theory of the aetiology of sexual offending. In: Marshall, W. L., Laws, D. R. and Barbaree, H.E. (Eds.) Handbook of Sexual Assault: Issues, Theories, and Treatment of the Offender, New York: Plenum, 257-275.

Meier, A. M. 2003. Adolescents' transition to first intercourse, religiosity, and attitudes about Sex. Social Forces 81(3), 1031-1052.

Menon, P. K.1983. The law of rape and criminal law administration with special reference to the commonwealth Caribbean', International and comparative law Quarterly 32 (4), 832-870.

Moore, K. A., Miller, B. G., Sugland, B. W., Morrison, D. R., Glei, D.A., and Blumenthal, G. 2006. Beginning too soon: Adolescent sexual behaviour, pregnancy and parenthood, a review of research and interventions. Washington, DC: Government Printing Office.

Neema S., Fatima H., Kibombo, A. R. and Bankole, A. 2006. Adolescent sexual and reproductive health in Uganda: results from the 2004 Uganda national survey of adolescents. Occasional Report No.25, New York: Guttmacher Institute.

$\mathrm{Ng}, \mathrm{C}$, J. and Kamal S. F. 2006. Bridging the gap between adolescent sexuality and HIV risk: the urban Malaysian perspective. Singapore Medical Journal 47(6), 482 - 490.

Parent, A. S., Teilmann, G., Juul, A., Skakkebaek, N. E., Toppari, J. and Bourguignon, J. P. 2003. Timing of Puberty around the World. Endocrine Reviews 24(5), 668-693.

Peterson, Z. D. and Muehlenhard, C. L. 2007. Conceptualizing the "Wantedness" of women's consensual and non-consensual sexual experiences: implications for how women label their experiences with rape. Journal of Sex Research, 44(1), 72-88.

Population Reference Bureau (PRB). 2006. World population data sheet. Washington, DC: PRB.

Povey, D., Cotton, J., and Sisson, S. 2000. Recorded Crime Statistics England and Wales, April 1999 to March 2000', Issue 12/00, London: Home Office.

Reiss, A.1960. Sex offences-the marginal status of the adolescent', Law \& Contemporary Problem $25,309-325$.

Remez.2000. 'Oral sex among adolescents: is it sex or is it abstinence? Family Planning Perspectives Special report 32(6), 296-304.

Robins, S. L. 2000. Protecting our Students: a review to identify and prevention of Sexual misconduct in Ontario Schools, Executive Summary and Recommendations. Toronto: Ontario Ministry of the Attorney.

Robinson, S. L. 2002. Treatment Manual. Growing Beyond, a Workbook for Sexually Abusive Teenage Girls. Holyoke, MA: NEARI Press.

Singh, S., Darroch, J. E. and Frost, J. J. 2001. 'Socio-economic disadvantage and adolescent women's sexual and reproductive behaviour, the case of five developed countries', Family Planning Perspectives 33(6), 251-289. 
Stammers, T. 2000. For and against: doctors should advise adolescents to abstain from sex. British Medical Journal 321, 1520-1522.

Stammers, T.1998. Adolescent sexuality. Christian Medical Fellowship Files, No. 4.

Sylvester, S.1987. Crime prevention and criminal justice, in search of a silver bullet' Annals of the American Academy of Political and Social Science, Vol. 494, Policies to Prevent Crime: Neighbourhood, Family, and Employment Strategies. 119-128.

Tamale, S. 2005. Eroticism, sensuality and "women's secrets" among the Baganda, a critical analysis. Feminist Africa 5.

Tan, N. 2001. Age of Consent, Lowering of: Should age of consent laws be made more liberal? International Debate Education Association

Todd, J. Currie, C and Smith, R. 1999. Health Behaviours of Scottish Schoolchildren: Technical Report 2: Sexual Health in the 1990s. University of Edinburgh Medical School and HBSC: WHO Cross-National Study.

Tyler, T. R. (1990), Why People Obey the Law. New Haven, CT: Yale University Press.

United Nations Department of International Economic and Social Affairs. (1989).Adolescent reproductive behaviour: Evidence from developing countries. Population Studies Report No. 109, Vol. 2. New York: United Nations.

Von Hirsch, A., Bottoms, A. E., Burney, E. and Wikstrom, O.-O. 1999. Criminal Deterrence and Sentence Severity. Oxford: Hart Publishing.

Walker, J. and Milton, J. 2006. Teachers' and parents' roles in the sexuality education of primary school children, a comparison of experiences in Leeds, UK and in Sydney, Australia', Sex Education, 6(4), 415 - 428.

Ward, T. and Keenan, T. 1999. Child molesters' implicit theories', Journal of Interpersonal Violence, 14(8), 821-838.

Wazir, R. and van Oudenhoven, N. (Eds.) 1998. Child Sexual Abuse: What can Governments Do? A comparative Investigation into Policy Instruments used in Belgium, Britain, German, the Netherlands and Norway, The Hague: Kluwer Law International.

Wilder, E. I. and Watt, T. T. 2002. Risky parental behaviour and adolescent sexual activity at first coitus. The Milbank Quarterly 80(3), 481-524.

Yisrael, D.S. 2005. Wimps, studs, virgins, and bad girls: How gender roles affect sexual health and everything else. Session conducted at the annual meeting of the American College Health Association, San Diego, CA.

Zimring, F. 2004. An American Travesty: Legal Responses to Adolescent Sexual Offending, Chicago: University of Chicago Press.

\section{Other Documentary Sources Applied}

Case Law [The High Court Bulletins (HCB) and Supreme Court Appeals] of Uganda.

Case Law [The High Court of Justice Queen's Bench Division Crown Office List Divisional Court] (online) Royal Courts of Justice Strand, London, WC2A 2LL. Retrieved 20 May 2007 from: http://www.geocities.com/pca_1978/reference/COA-atkins.html

Reports from the Uganda Human Rights Commission.

The 1995 constitution of Uganda.

The Penal Code Act, Chapter 120 of the Laws of Uganda.

The Ugandan Evidence Act

\section{Author Biography}

Nathan Muwereza is a PhD Candidate at the International Max Planck Research School on Retaliation, Mediation and Punishment (IMPRS REMEP) at the Max Planck Institute for Foreign and International Criminal Law, Albert Ludwig University, Germany. He is the founder and director of African Community Team Support (ACTS). 